medRxiv preprint doi: https://doi.org/10.1101/2020.04.05.20036574; this version posted April 8, 2020. The copyright holder for this preprint (which was not certified by peer review) is the author/funder, who has granted medRxiv a license to display the preprint in perpetuity.

All rights reserved. No reuse allowed without permission.

1

4

5

6

7

8

9

10

Community transmission of rotavirus infection in a vaccinated population in Malawi: a prospective household cohort study

Aisleen Bennett PhD ${ }^{1,2,3}$, Louisa Pollock PhD ${ }^{1,2}$, Naor Bar-Zeev PhD ${ }^{1,4}$, Joseph A. Lewnard PhD ${ }^{5}$, Khuzwayo C. Jere $\mathrm{PhD}^{1,2}$, Benjamin Lopman $\mathrm{PhD}^{6}$, Miren Iturriza-Gomara PhD ${ }^{1,2,7}$, Virginia E. Pitzer ScD*8, Nigel A. Cunliffe PhD*1,2,7

1.Malawi-Liverpool-Wellcome Trust Clinical Research Programme, College of Medicine, University of Malawi, Blantyre, Malawi.

2. Centre for Global Vaccine Research, Institute of Infection \& Global Health, University of Liverpool, Liverpool, UK

3. Institute of Infection and Immunity, St George's, University of London, UK

4. International Vaccine Access Center, Bloomberg School of Public Health, John Hopkins 2 University, Baltimore, USA

5. School of Public Health, Berkley, University of California

6. Department of Epidemiology, Rollins School of Public Health, Emory University, Atlanta, USA

7. NIHR Health Protection Research Unit in Gastrointestinal Infections, University of Liverpool, Liverpool, UK

8. Department of Epidemiology of Microbial Diseases, Yale School of Public Health, Yale University, New Haven, USA.

*Contributed equally

Corresponding author details: Institute of Infection and Global Health, The Ronald Ross Building, University of Liverpool, 8 West Derby Street, Liverpool

\title{
Email abennett@sgul.ac.uk
}

\section{Word count}

Abstract: 250

Text: 3286

NOTE: This preprint reports new research that has not been certified by peer review and should not be used to guide clinical practice. 
medRxiv preprint doi: https://doi.org/10.1101/2020.04.05.20036574; this version posted April 8, 2020. The copyright holder for this preprint (which was not certified by peer review) is the author/funder, who has granted medRxiv a license to display the preprint in perpetuity.

All rights reserved. No reuse allowed without permission.

27

\section{Abstract}

\section{Background}

Rotavirus vaccine effectiveness (VE) is reduced among children in low-income countries (LICS). Indirect (transmission-mediated) effects of rotavirus vaccine may contribute to the total population impact of vaccination. We estimated the effectiveness of rotavirus vaccine in preventing transmission of rotavirus to household contacts in Blantyre, Malawi.

\section{Methods}

We recruited vaccine-age-eligible children with acute rotavirus gastroenteritis (case-children), together with their household contacts. Clinical data and stool samples were collected from case-children at presentation, and prospectively from household contacts over 14 days. A single stool sample was collected from control households containing asymptomatic children age-matched to case-children. Samples were tested for rotavirus using real-time PCR. Risk factors for household transmission of rotavirus infection and clinical rotavirus disease were identified using logistic regression. Vaccine effectiveness against transmission $\left(V_{T}\right)$ was estimated as one minus the ratio of secondary attack rates (SAR) in vaccinated and unvaccinated populations, using VE estimates from the associated diarrhoeal surveillance platform to estimate the counterfactual SAR without vaccination.

\section{Findings}

A total of 196 case-households and 55 control-households were recruited. Household SAR for rotavirus infection was high (65\%); SAR for clinical disease was much lower (5\%). Asymptomatic infection in control households was common (28\%). Increasing disease severity was associated with increased risk of transmission of both rotavirus infection and disease to household contacts. Estimated $V E_{T}$ was 39\% (95\% confidence interval 16-57\%).

\section{Interpretation}

Rotavirus vaccine has the potential to substantially reduce household rotavirus transmission. This should be considered in clinical and health economic assessments of vaccine impact.

\section{Funding}

Wellcome Trust and NIH/NIAID. 
medRxiv preprint doi: https://doi.org/10.1101/2020.04.05.20036574; this version posted April 8, 2020. The copyright holder for this preprint (which was not certified by peer review) is the author/funder, who has granted medRxiv a license to display the preprint in perpetuity.

All rights reserved. No reuse allowed without permission.

\section{Introduction}

Rotavirus vaccine has been introduced into over 90 countries worldwide, including 45 low- and middle-income countries (LMICS) ${ }^{1}$. However, rotavirus vaccine effectiveness (VE) is reduced in low-income countries (LICS), where disease burden is highest, compared to high-income countries $^{2}$. Thus, despite high vaccine coverage, rotavirus remains the commonest cause of hospitalised diarrhoeal disease in some LICs ${ }^{3}$. Since direct VE is reduced in LMICs, additional transmission-mediated (indirect) effects of the vaccine have the potential to make important contributions to population-level vaccine impact. However, both the presence and extent of rotavirus indirect effects, and the mechanisms which underpin them, are poorly understood ${ }^{4}$.

Rotavirus vaccination mimics immunity induced by natural rotavirus infections, which confer incremental protection against severe rotavirus disease to a degree which varies by location ${ }^{5-}$ 7. Rotavirus disease severity has been demonstrated to correlate with faecal rotavirus shedding density in India and Malawi ${ }^{8}$, and available evidence suggests that severity of symptoms is related to the risk of transmission ${ }^{9}$. It is therefore plausible that vaccination, while not providing complete protection against disease, may reduce the severity of gastroenteritis and diminish viral shedding following exposure to natural rotavirus infection, leading to reduced infectiousness of an index case, a lower secondary attack rate (SAR) in exposed households, and reduced rotavirus transmission.

There are currently no published data describing household transmission of rotavirus from subSaharan Africa. Previous studies in high-income settings have demonstrated a high SAR within families and have highlighted the role of infants in introducing rotavirus infection into households ${ }^{10,11}$. A household transmission study in Ecuador demonstrated a SAR of $55 \%$ for asymptomatic infection ${ }^{9}$. However, extrapolation of data on rotavirus transmission from highand middle-income countries to LICS is not appropriate because of fundamental differences in factors that may have a major influence on the risk of transmission such as living environments, crowding, contact patterns, access to sanitation systems, host immunity and frequency of exposure to rotavirus ${ }^{4}$.

This study aimed to investigate household rotavirus transmission in a semi-urban setting in Blantyre, Malawi, where the monovalent, G1P[8]-containing rotavirus vaccine (RV1), was introduced into the childhood immunisation programme in 2012. Our objectives were to (i) 
medRxiv preprint doi: https://doi.org/10.1101/2020.04.05.20036574; this version posted April 8, 2020. The copyright holder for this preprint (which was not certified by peer review) is the author/funder, who has granted medRxiv a license to display the preprint in perpetuity.

All rights reserved. No reuse allowed without permission.

85

86

87

88

89

90

91

92

93

94

95

96

97

98

99

100

101

102

103

104

105

106

107

108

109

110

111

112

113

explore risk factors for transmission of rotavirus to household contacts, including symptom severity and faecal rotavirus shedding density, and (ii) estimate the effectiveness of rotavirus vaccine in preventing transmission of rotavirus infection to household contacts.

\section{Methods}

\section{Recruitment and study design}

We conducted a prospective cohort study across four government health facilities in Blantyre, Malawi between February 2015 and November 2016. These health facilities included Queen Elizabeth Central Hospital (QECH), the primary referral centre for Southern Malawi; and three health centres (Zingwangwa, Gateway, and Madziabango). Vaccine-age-eligible children presenting with acute gastroenteritis were screened for rotavirus using a point-of-care immuno-chromatographic rapid test (Rota-Strip, Coris BioConcept, Gembloux, Belgium). Children testing positive for rotavirus (case children) were recruited together with their household contacts, following informed consent.

In order to estimate SARs, households were followed prospectively for 14 days after symptom onset in the case child; this comprised active surveillance for clinical disease and stool collection from household contacts to detect rotavirus infection (case cohort). Control households were recruited in order to define the background prevalence of rotavirus infection in households in the community. Control households each contained an asymptomatic child frequency-matched based on age to case children, and were recruited from randomly generated Global Positioning System (GPS) locations in Blantyre district. Control households were excluded if there was a history of symptoms of gastroenteritis in any household member in two weeks prior to recruitment. Sample size estimates are detailed in the supplementary materials.

\section{Data collection}

Clinical data were collected from case children including anthropometric measurements and assessment of disease severity using the standardised 20-point Vesikari score ${ }^{12}$. Demographic, risk factor and symptom questionnaires were completed for household contacts and control households upon recruitment. Receipt of rotavirus vaccine and HIV status were documented from government-issued, hand-held health passports. 
medRxiv preprint doi: https://doi.org/10.1101/2020.04.05.20036574; this version posted April 8, 2020. The copyright holder for this preprint (which was not certified by peer review) is the author/funder, who has granted medRxiv a license to display the preprint in perpetuity.

All rights reserved. No reuse allowed without permission.

Participants were defined as HIV infected if positive on HIV rapid test (children $>12$ months), or HIV DNA PCR (infants $<12$ months) ${ }^{13}$. Severe acute malnutrition (SAM) was defined using WHO criteria of weight-for-height Z score $(\mathrm{WHZ}) \leq 3$ standard deviations from the median or mid-upper arm circumference (MUAC) $\leq 11 \cdot 5 \mathrm{~cm}^{14}$.

\section{Sample collection}

Case children with acute gastroenteritis had bulk stool and $1-2 \mathrm{ml}$ of serum collected at presentation for measurement of rotavirus viral load and anti-rotavirus immunoglobin A (IgA) titres, respectively. Stool samples were collected from household contacts at days 5-7 and 1012 after symptom onset in the case child. Control household members had a single stool sample collected at the point of recruitment.

\section{Laboratory analysis}

Faecal samples were tested for rotavirus using a VP6 semi-quantitative real-time PCR (qRT$P C R)^{15}$. A standard curve was included in each run to allow estimation of rotavirus viral load (copy numbers). Samples with Ct value $>35$ and $<40$ on VP6 PCR underwent confirmatory testing with a second qRT-PCR assay targeting the NSP3 gene ${ }^{16}$. Samples were defined as rotavirus positive if they contained $\geq 100$ viral copy numbers and were positive on NSP3 assay. All rotavirus-antigen-positive samples from case children, and rotavirus qRT-PCR-positive samples from household members with a Ct value of $\leq 35$, underwent $G$ - and P-typing using a two-stage PCR with consensus and random primers ${ }^{17}$. Anti-rotavirus IgA geometric mean titres (IU/ml IgA) were measured using a semi-quantitative sandwich ELISA ${ }^{18}$ and were calculated using a minimum of two values per sample with a coefficient of variation (CV) $<20 \%$. Results were defined as zero if below the lower limit of detection. Clinical disease in household contacts was defined as any reported vomiting or diarrhea during the follow-up period.

\section{Statistical analysis}

Distributions of continuous variables were examined and categorical variables were tabulated to generate descriptive statistics. Missing observations were assumed to be missing completely at random. Two-sided t-tests were used to compare independent means of normally distributed data, and rank-sum tests were used to compare non-normally distributed data. Chisquared or Fischer's exact tests were used to compare categorical variables. 
medRxiv preprint doi: https://doi.org/10.1101/2020.04.05.20036574; this version posted April 8, 2020. The copyright holder for this preprint (which was not certified by peer review) is the author/funder, who has granted medRxiv a license to display the preprint in perpetuity.

All rights reserved. No reuse allowed without permission.

143

Risk factors for rotavirus transmission within case households were identified using logistic regression models with a random effect to account for household-level clustering. A conceptual framework (Figure 1) was developed to account for the hierarchical relationship between predictive variables ${ }^{19}$. Variables were divided into two initial groups: those relating to the infectiousness of the symptomatic case child and those relating to the susceptibility of household contacts. Susceptibility variables were further divided into proximal susceptibility (individual level), and distal susceptibility (household level) variables. Individual models were built for each group to identify risk factors of importance whilst adjusting for potential confounding. A final model was then built incorporating all three groups, beginning with distal susceptibility variables then adding proximal susceptibility variables and infectiousness variables. Separate models were built for infection and disease. All variables with $p<0.1$ on univariable analysis were tested for inclusion in the final models. Nested models were compared using likelihood ratio tests. Variables were retained in the model if $p<0 \cdot 1$ at any stage of the procedures outlined above.

\section{Estimating vaccine effectiveness against transmission $\left(\mathrm{VE}_{\mathrm{T}}\right)$}

Vaccine effectiveness against transmission of rotavirus infection ( $\left.V E_{T}\right)$ was estimated using the following approach:

1. Children were divided into three severity groups: very severe disease (Vesikari score 215 ), less severe disease (Vesikari score $<15$ ) and asymptomatic infection. SAR for infection among household contacts of index cases with very severe $(V)$ and less severe $(M)$ disease and of asymptomatic children $(A)$ was estimated using data from the household transmission study. The prevalence of asymptomatic infection in household members of control households was used as an estimate of SAR for asymptomatic children, accepting that this is likely to be an over-estimate. Receiver operating characteristics (ROC) analysis together with Youden's index ${ }^{20}$ was used verify that a cutoff of severity score 15 had good discriminatory power in differentiating risk of transmission (Figure S1).

2. We assumed that receipt of rotavirus vaccination would have resulted in children from the "very severe" disease category moving into the "less severe" category and children from the "less severe" category moving into an "asymptomatically infected" category 
medRxiv preprint doi: https://doi.org/10.1101/2020.04.05.20036574; this version posted April 8, 2020. The copyright holder for this preprint (which was not certified by peer review) is the author/funder, who has granted medRxiv a license to display the preprint in perpetuity.

All rights reserved. No reuse allowed without permission. at a proportion determined by the respective VE estimates (Figure 2). The number of vaccinated children with very severe (SV) and less severe (MV) disease was observed in the household transmission study. The number of children with very severe rotavirus disease in a hypothetical unvaccinated population $(S U)$ was estimated as $S U=S V /(1-$ $\left.V E_{S}\right)$, where $V E_{s}$ is the vaccine effectiveness against very severe disease. Similarly, the number of children with less severe disease in an unvaccinated population (MU) was estimated as $M U=M V /\left(1-V E_{M}\right)$, where $V E_{M}$ is the vaccine effectiveness against less severe disease. The total number of children with very severe or less severe rotavirus disease in an unvaccinated population was therefore:

$$
n=S U+M U=\frac{S V}{1-V E_{S}}+\frac{M V}{1-V E_{M}} .
$$

3. Vaccine effectiveness against very severe and less severe rotavirus disease were calculated as 1 minus the odds ratio (OR) of 2 versus 0 doses of vaccine. ORs were estimated using logistic regression models fit to data from the rotavirus surveillance platform in Blantyre, Malawi. Under idealised test-negative case-control designs, the OR provides an unbiased estimate of the relative risk $(R R)^{21}$;

4. Vaccine effectiveness against transmission $\left(V E_{T}\right)$ was estimated as 1 minus the ratio of the SARs in vaccinated and unvaccinated populations using the following equation:

$$
V E_{T}=1-\frac{\left(S A R_{S} P_{S V}\right)+\left(S A R_{M} P_{M V}\right)+\left(S A R_{A} P_{A V}\right)}{\left(S A R_{S} P_{S U}\right)+\left(S A R_{M} P_{M U}\right)}
$$

where $S A R_{x}$ is the household secondary attack rate of infection for a household with an index child experiencing infection severity $x$, and $P_{x y}$ indicates the proportion of index children (cases or controls) with rotavirus infection of severity $x$ and vaccination status y. Proportions were estimated as: $\left.P_{S V}=S V / n, P_{M V}=M V / n, P_{A V}=(n-S V-M V) / n\right), P_{S U}=S U / n$, $P_{M U}=M U / n$

Bootstrapped $95 \%$ confidence limits for $V E_{T}$ were generated by sampling 10,000 times from the distributions of the corresponding parameters. Bootstrap samples of VE (1-OR) for very severe and less severe disease were generated by sampling from log-normal distributions using the mean and standard deviation derived from logistic regression models in step 3.

\section{Ethics}


medRxiv preprint doi: https://doi.org/10.1101/2020.04.05.20036574; this version posted April 8, 2020. The copyright holder for this preprint (which was not certified by peer review) is the author/funder, who has granted medRxiv a license to display the preprint in perpetuity.

All rights reserved. No reuse allowed without permission.

203

204

205

206

207

208

209

210

211

212

213

214

215

216

217

218

219

220

221

222

223

224

225

226

227

The study was approved by the University of Liverpool Research Ethics committee (\# 000757), and the Malawi College of Medicine Research Ethics Committee (P.09/14/1623).

\section{Results}

\section{Characteristics of index children and households}

A total of 196 case households containing a symptomatic rotavirus-positive case child, and 55 control households containing a frequency age-matched asymptomatic child were recruited. Median age was 11.5 months among both cases and age-matched control children; 55\% of rotavirus-positive case children and $47 \%$ of control children were males $(p=0 \cdot 3)$ (Table 1$)$. Rotavirus vaccine coverage was high ( $\geq 99.0 \%$ among both cases and controls). Household characteristics are listed in Tables S1 and S2. Anti-rotavirus IgA titres in case children at presentation were low (median $4 \mathrm{IU} / \mathrm{ml}$ ). Viral loads in case children were high, with a median Ct value of $19 \cdot 1$ (interquartile range (IQR) $17 \cdot 2,22 \cdot 2$ ) corresponding to median copy numbers of $1.67 \times 10^{7}\left(\operatorname{IQR} 1.63 \times 10^{6}, 6.37 \times 10^{7}\right)$. Viral loads in household contacts were markedly lower; median Ct value was 34.8 (IQR 31.8, 36.6), corresponding to a median viral load of 712 (IQR 256, 3704).

\section{Secondary attack rates}

A total of 705 household members were recruited from 196 case households. At least one faecal sample was collected from 665 individuals from 188 case households, with a total of 1212 samples collected. The SAR for infection among household contacts of case children was high, with $65 \%$ of individuals positive for rotavirus (Table 2 ). Secondary attack rates for disease were much lower, with 48/699 (7\%) household contacts reporting symptoms of gastroenteritis. Of these, 47 had samples available for testing and 37 (77.1\%) were positive for rotavirus, resulting in a SAR for clinical rotavirus disease of $37 / 698$ (5.3\%). Rates of clinical disease were significantly higher among children $<5$ years $(12 / 91,13 \cdot 2 \%, p<0 \cdot 001)$.

The prevalence of rotavirus shedding in the control households was $27 \cdot 8 \%(40 / 144)$, significantly lower than in case households (Table 2).

\section{Rotavirus genotypes}

Of 195 samples from case children with available genotyping data, almost a third were genotype G2P[4] (30.8\%). The next most frequent genotypes were G1P[8] (24.6\%), G2[P6] 
medRxiv preprint doi: https://doi.org/10.1101/2020.04.05.20036574; this version posted April 8, 2020. The copyright holder for this preprint (which was not certified by peer review) is the author/funder, who has granted medRxiv a license to display the preprint in perpetuity.

All rights reserved. No reuse allowed without permission.

(14.4\%) and G12P[6] (8.2\%) (Figure S2). A total of 297 samples were genotyped from household contacts of cases; in almost one third (94/297, 31.6\%) both $G$ and P types were the same as those identified in the case child. Comparison of genotypes in case children and household contacts are reported in Table S3. Only seven samples from control households could be genotyped due to low viral load in most control samples (data not shown).

\section{Risk factors for transmission of rotavirus infection}

Increasing disease severity (per Vesikari score unit) in the case child was strongly associated with transmission to household contacts (OR 1.17, 95\% Cl 1.06, 1.30; $p=0 \cdot 003$, Table 3). MUAC in the case child was also positively associated with risk of transmission. At the household level (distal susceptibility factors), having at least one household member with a regular salary was associated with reduced susceptibility to infection. Conversely, a recent history of difficulty obtaining sufficient food for the household was also associated with reduced susceptibility to infection. At the individual level (proximal susceptibility factors), there was strong evidence that the proximity of relationship with the case child was associated with risk of transmission, with mothers significantly more likely to become infected with rotavirus than other adult relatives or child household contacts (Table 3). Univariate associations for risk of transmission of infection are detailed in Tables S4-S6.

\section{Risk factors for transmission of rotavirus disease}

The primary infectiousness risk factor was disease severity in the index case, with a positive association between increasing disease severity and risk of clinical rotavirus disease in household contacts (Table 4). There was evidence of a weak association between genotype of rotavirus in the index child and risk of disease transmission, with an increased risk of transmission with G1P[8] genotype compared to G2P[4], G2P[6] and G12P[6]. At the household level (distal susceptibility factors), use of a pit or water toilet was associated with a reduced odds of rotavirus disease compared to having no toilet, though this association was no longer statistically significant in the final model. At the individual level (proximal susceptibility factors), age of the household contact was significantly associated with risk of disease; children aged $<5$ years had the greatest risk of disease compared to children aged 5-15 years and older adults. Univariate associations for risk of disease are presented in Tables S7-S9. 
medRxiv preprint doi: https://doi.org/10.1101/2020.04.05.20036574; this version posted April 8, 2020. The copyright holder for this preprint (which was not certified by peer review) is the author/funder, who has granted medRxiv a license to display the preprint in perpetuity.

All rights reserved. No reuse allowed without permission.

262

263

264

265

266

267

268

269

270

271

272

273

274

275

276

277

278

279

280

281

282

283

284

285

286

287

288

289

290

291

\section{Vaccine Effectiveness against Transmission $\left(\mathrm{VE}_{\mathrm{T}}\right)$}

Vaccine effectiveness against very severe and less severe rotavirus disease were estimated to be $69 \%(95 \% \mathrm{Cl}:-10,91 \%)$ and $56 \%(95 \% \mathrm{Cl} 3,79 \%)$, respectively, based on the diarrhoeal surveillance dataset. As a result, we estimated that the proportion of unvaccinated children with very severe disease would be $0.44(95 \% \mathrm{Cl} 0.15,0.78)$ and the proportion of unvaccinated children with less severe disease would be 0.55 (95\% Cl 0.22, 0.85). In comparison, the proportion of vaccinated children with very severe and less severe disease were estimated to be $0.13(95 \% \mathrm{Cl} 0.06,0.27)$ and $0.23(95 \% \mathrm{Cl} 0.11,0.47)$, respectively, and the proportion of vaccinated children who became asymptomatic was estimated to be $0.63(95 \% \mathrm{Cl} 0.27,0.83)$. The SARs for severe disease, less severe disease, and asymptomatic infection were estimated to be $72 \%(95 \% \mathrm{Cl} 64 \%, 79 \%), 64 \%(95 \% \mathrm{Cl} 57 \%, 69 \%)$, and $25 \%$ (95\% Cl 16\%, 35\%), respectively. Combining this information in equation 2, we estimated a VET of $39 \%(95 \% \mathrm{Cl} 16 \%$, 57\%) (Figure 3).

\section{Discussion}

In Malawi, very high attack rates (65\%) for rotavirus infection were observed in households following contact with a symptomatic rotavirus case despite very high rotavirus vaccine coverage. However, the attack rate for rotavirus disease was much lower (5\%). Disease severity in the index child was an important predictor of transmission of both infection and disease to household contacts. We estimated a VE against transmission of rotavirus infection (VET) of $39 \%$.

The majority of case children in our study represent rotavirus vaccine failures; high viral shedding density and low anti-rotavirus IgA titres at the time of presentation likely explains the high SAR. Our estimate of SAR for rotavirus infection is consistent with studies from New Zealand and Ecuador, which reported SARs for rotavirus infection of $48 \%$ and 55\%, respectively ${ }^{9,10}$. In contrast, we observed much lower overall attack rates for clinical disease (5\%), compared with $15 \%$ and $38 \%$ reported for Ecuador and New Zealand, respectively. This difference could be explained by a high background force of rotavirus infection in Malawi resulting in frequent "boosting" of immunity against clinical disease, particularly among older children and adult; of note, the clinical SAR was highest in children aged 0-4 years ${ }^{22}$. We also observed a high frequency of rotavirus infection (28\%) in control households. Whilst this is 
medRxiv preprint doi: https://doi.org/10.1101/2020.04.05.20036574; this version posted April 8, 2020. The copyright holder for this preprint (which was not certified by peer review) is the author/funder, who has granted medRxiv a license to display the preprint in perpetuity.

All rights reserved. No reuse allowed without permission.

292

293

294

295

296

297

298

299

300

301

302

303

304

305

306

307

308

309

310

311

312

313

314

315

316

317

318

319

320

321

322

substantially greater than observed in higher income settings, such as the UK and Ecuador ${ }^{9,23}$, it is consistent with published studies from sub-Saharan Africa ${ }^{24,25}$, and is plausible given the high force of rotavirus infection in Malawi ${ }^{22}$ and high levels of poverty, crowding, and poor access to water and sanitation. The inconsistencies between rotavirus genotypes detected in case children and their household contacts may also reflect the high frequency of asymptomatic shedding identified in the community 9 .

Increasing disease severity was associated with increased odds of rotavirus transmission for both infection and disease; by reducing disease severity, rotavirus vaccine has the potential to reduce the infectiousness of a symptomatic index case even in the event of clinical vaccine failure. This is a phenomenon described with other pathogens such as pertussis, but not as yet with rotavirus ${ }^{26}$. In this study, we estimated that in a semi-urban population in Malawi, with extremely high rates of rotavirus transmission, rotavirus vaccine reduces population-level rotavirus transmission by $39 \%$. Such a reduction in transmission has the potential to make a considerable impact on the burden of rotavirus disease in the community, and is consistent with previous estimates of indirect effectiveness of rotavirus vaccination from Malawi from hospital-based studies and mathematical models ${ }^{22,27}$. In contrast, horizontal transmission of vaccine virus is unlikely to make a significant contribution to indirect effects in this setting, since vaccine transmission within households is rare ${ }^{28}$.

Lack of a regular salary in the household increased the risk of transmission of infection. This likely reflects relative poverty, which could increase rotavirus transmission for reasons including crowding, sanitation, or carer education levels, or other unmeasured factors. Close contact and proximity of relationship to the index child also increased the risk of transmission of infection, emphasising the role that personal/hand hygiene and behavioural measures may play in preventing rotavirus transmission within households. Rotavirus genotype G1P[8] was weakly associated with an increased risk of transmission, consistent with the global predominance of G1P[8] prior to widespread introduction of vaccination.

Our study has important limitations. Firstly, the direction of infection cannot be defined with certainty using this study design, since households were recruited only when an index child presented with rotavirus gastroenteritis; however, the pattern of transmission supports young infants bringing rotavirus into the household. Secondly, our estimate of $V E_{T}$ assumes that asymptomatic infections contribute a relatively small amount to the overall SAR, and that the 
medRxiv preprint doi: https://doi.org/10.1101/2020.04.05.20036574; this version posted April 8, 2020. The copyright holder for this preprint (which was not certified by peer review) is the author/funder, who has granted medRxiv a license to display the preprint in perpetuity.

All rights reserved. No reuse allowed without permission.

prevalence of asymptomatic infection is similar or lower in an unvaccinated population. The prevalence of asymptomatic infections among vaccinated infants and VE against asymptomatic infection are unknown. Furthermore, $V E_{T}$ is dependent on locally-specific parameters, and our estimate may not be generalisable to other settings.

Despite sustained high coverage of rotavirus vaccine in Malawi and other low-income African countries, the burden of rotavirus disease remains high. We demonstrated frequent transmission of rotavirus infection from symptomatic, vaccinated children in Malawi to their household contacts and high background rates of asymptomatic rotavirus shedding. Our estimate of rotavirus vaccine effectiveness against transmission of infection of $39 \%$ suggests indirect protection has the potential to substantially contribute to vaccine impact on community disease burden. Together with direct vaccine effectiveness estimates, indirect or "herd" protection should be considered in future health economic assessments of rotavirus vaccine impact. This may be particularly relevant in low-income, high-disease-burden environments.

\section{References}

1 Rotavirus vaccine support - Gavi, the Vaccine Alliance.

2 Madhi SA, Cunliffe NA, Steele D, et al. Effect of human rotavirus vaccine on severe diarrhea in African infants. N Engl J Med 2010; 362: 289-98.

3 Platts-Mills JA, Amour C, Gratz J, et al. Impact of Rotavirus Vaccine Introduction and Postintroduction Etiology of Diarrhea Requiring Hospital Admission in Haydom, Tanzania, a Rural African Setting. Clinical Infectious Diseases 2017; 62: S213-9.

4 Bennett A, Bar-Zeev N, Cunliffe NA. Measuring indirect effects of rotavirus vaccine in low income countries. Vaccine 2016; 34: 4351-3.

5 Gladstone BP, Ramani S, Mukhopadhya I, et al. Protective effect of natural rotavirus infection in an Indian birth cohort. N Eng/ J Med 2011; 365: 337-46.

6 Fischer TK, Valentiner-branth P, Steinsland H, Perch M, Santos G, Aaby P. Protective Immunity after Natural Rotavirus Infection: A Community Cohort Study of Newborn Children in Guinea-Bissau , West Africa. 1998; : 593-7.

7 Velazquez FR, Matson DO, Calva JJ, et al. Rotavirus infections in infants as protection against subsequent infections. N Engl J Med 1996; 335: 1022-8. 
medRxiv preprint doi: https://doi.org/10.1101/2020.04.05.20036574; this version posted April 8, 2020. The copyright holder for this preprint (which was not certified by peer review) is the author/funder, who has granted medRxiv a license to display the preprint in perpetuity.

All rights reserved. No reuse allowed without permission.

8 Mukhopadhya I, Sarkar R, Menon VK, et al. Rotavirus shedding in symptomatic and asymptomatic children using reverse transcription-quantitative PCR. J Med Virol 2013; 85: 1661-8.

9 Lopman B, Vicuna $Y$, Salazar F, et al. Household transmission of rotavirus in a community with rotavirus vaccination in Quininde, Ecuador. PLoS One 2013; 8: e67763.

10 Grimwood K, Abbott GD, Fergusson DM, Jennings LC, Allan JM. Spread of rotavirus within families: a community based study. Br Med J (Clin Res Ed) 1983; 287: 575-7.

11 Koopman JS, Monto AS, Longini Jr. IM. The Tecumseh Study. XVI: Family and community sources of rotavirus infection. Am J Epidemiol 1989; 130: 760-8.

12 Ruuska T, Vesikari T. Rotavirus disease in Finnish children: use of numerical scores for clinical severity of diarrhoeal episodes. Scand J Infect Dis 1990; 22: 259-67.

13 Ministry of Health. 2014 Clinical Management of HIV In Children and Adults. 2014; : 100.

14 World Health Organisation. WHO child growth standards and the identification of severe acute malnutrition in infants and children. WHO/UNICEF joint statement. 2009.

15 Kang G, Iturriza-Gomara M, Wheeler JG, et al. Quantitation of group A rotavirus by real-time reverse-transcription-polymerase chain reaction: correlation with clinical severity in children in South India. J Med Virol 2004; 73: 118-22.

16 Freeman MM, Kerin T, Hull J, McCaustland K, Gentsch J. Enhancement of detection and quantification of rotavirus in stool using a modified real-time RT-PCR assay. J Med Virol 2008; 80: 1489-96.

17 Iturriza-Gómara M, Dallman T, Bányai K, et al. Rotavirus genotypes co-circulating in Europe between 2006 and 2009 as determined by EuroRotaNet, a pan-European collaborative strain surveillance network. Epidemiology and infection 2011; 139: 895909.

18 Bernstein DI, Smith VE, Sherwood JR, et al. Safety and immunogenicity of live, attenuated human rotavirus vaccine 89-12. Vaccine 1998; 16: 381-7.

19 Victora, Cesar Huttly, Sharon Fuchs, Olinto M. The Role of Conceptual Frameworks in Epidemiological Analysis:A Heirarchical Approach. Internional Journal of Epidemiology 1997; 26.

20 Fluss R, Faraggi D, Reiser B. Estimation of the Youden Index and its associated cutoff point. Biom J 2005; 47: 458-72.

21 Foppa IM, Haber M, Ferdinands JM, Shay DK. The case test-negative design for studies of the effectiveness of influenza vaccine. Vaccine 2013. DOI:10.1016/j.vaccine.2013.04.026. 
medRxiv preprint doi: https://doi.org/10.1101/2020.04.05.20036574; this version posted April 8, 2020. The copyright holder for this preprint (which was not certified by peer review) is the author/funder, who has granted medRxiv a license to display the preprint in perpetuity.

All rights reserved. No reuse allowed without permission.

22 Pitzer VE, Bennett A, Bar-Zeev N, et al. Evaluating strategies to improve rotavirus vaccine impact during the second year of life in Malawi. Science Translational Medicine 2019; 11. DOI:10.1126/scitranslmed.aav6419.

23 Phillips G, Lopman B, Rodrigues LC, Tam CC. Asymptomatic rotavirus infections in England: prevalence, characteristics, and risk factors. Am J Epidemiol 2010; 171: 102330 .

24 Ouédraogo N, Kaplon J, Bonkoungou IJO, et al. Prevalence and genetic diversity of enteric viruses in children with diarrhea in Ouagadougou, Burkina Faso. PLOS ONE 2016; 11: 1-22.

25 Bennett A, Bar-Zeev N, Jere KC, et al. Determination of a viral load threshold to distinguish symptomatic versus asymptomatic rotavirus infection in a high-diseaseBurden African population. Journal of Clinical Microbiology 2015; 53: 1951-4.

26 Preziosi MP, Halloran ME. Effects of pertussis vaccination on transmission: vaccine efficacy for infectiousness. Vaccine 2003; 21: 1853-61.

27 Bennett A, Pollock $L$, Jere KC, et al. Direct and possible indirect effects of vaccination on rotavirus hospitalisations among children in Malawi four years after programmatic introduction. Vaccine 2018; 36: 7142-8.

28 Bennett A, Pollock L, Jere KC et al. Infrequent Transmission of Monovalent Human Rotavirus Vaccine Virus to Household Contacts of Vaccinated Infants in Malawi. J Infect Dis. 2019 May 5;219(11):1730-1734.

\section{Figure legends}

Figure 1. Conceptual framework for multivariate model.

Figure 2. Conceptual diagram of the effect of vaccination on the proportion of children with rotavirus infection of different degrees of disease severity. In our study, we observed cases of very severe (SV) and less severe (MV) rotavirus diarrhoea among vaccinated children. We used the estimated vaccine effectiveness against very severe (VES) and less severe rotavirus diarrhoea $\left(V E_{M}\right)$ to infer the number of very severe $(S U)$ and less severe $(M U)$ rotavirus cases in an unvaccinated population. The dashed line represents the size of the potentially observable population ( $n$ ). Our analysis is conservative in that it assumes that the proportion of children who are asymptomatically infected or uninfected in a vaccinated population is greater than or equal to the corresponding proportions in an unvaccinated population. 
medRxiv preprint doi: https://doi.org/10.1101/2020.04.05.20036574; this version posted April 8, 2020. The copyright holder for this preprint (which was not certified by peer review) is the author/funder, who has granted medRxiv a license to display the preprint in perpetuity.

All rights reserved. No reuse allowed without permission.

423 Figure 3. Distribution of estimates for vaccine effectiveness against transmission $\left(V E_{T}\right)$. The histogram of 10,000 bootstrap samples of the estimated $V E_{T}$ is plotted.

425

\section{Contributors}

$A B$ had overall responsibilty for study design and execution, data analysis, and manuscript drafting, editing and writing. LP and NBZ contributed to study design, data collection and manuscript editing and writing. KCJ contributed to laboratory data collection and supervision and manucript editing. BL contributed to study design and data analysis. MIG contributed to study design, laboratory data collection and supervision, and manuscript editing. VEP contributed to study design, data analysis and manuscript editing and writing. NAC contributed to study design, data collection, and manuscript editing and writing.

\section{Declaration of interests}

$434 \mathrm{LP}, \mathrm{AB}, \mathrm{BL}$ : no conflict. NB-Z and K.C.J have received research grant support from GlaxoSmithKline Biologicals for work on rotavirus vaccines. MI-G has received research grant support from GlaxoSmithKline Biologicals and Sanofi Pasteur MSD for work on rotavirus. NAC has received research grant support and honoraria for participation in rotavirus vaccine advisory board meetings from GlaxoSmithKline Biologicals. V.E.P. is a member of the WHO Immunization and Vaccine-related Implementation Research Advisory Committee (IVIR-AC) and has received reimbursement from Merck for travel expenses to attend a Scientific Input Engagement unrelated to rotavirus vaccines

\section{Acknowledgements}

This study was supported by two Wellcome Trust Clinical PhD Fellowships [grant numbers 102466/Z/13/A to AB and 102464/Z/13/A to LP], a Wellcome Trust Programme Grant [grant number 091909/Z/10/Z], the MLW Programme Core Grant Strategic Award [grant number 101113/Z/13/Z] and by the U.S. National Institutes of Health/National Institute of Allergy and Infectious Diseases [grant number R01-Al112970 to VEP]. K.C.J. is supported by an International Wellcome Trust Training Fellowship (grant number: 201945/Z/16/Z). We thank all infants and their families who participated and all members of the RotaRITE study team. We are grateful for the support of the Malawi Ministry of Health and clinical staff at the recruitment sites. 
medRxiv preprint doi: https://doi.org/10.1101/2020.04.05.20036574; this version posted April 8, 2020. The copyright holder for this preprint (which was not certified by peer review) is the author/funder, who has granted medRxiv a license to display the preprint in perpetuity.

All rights reserved. No reuse allowed without permission.

Table 1. Characteristics of index and control children.

\begin{tabular}{|c|c|c|c|}
\hline & Case children & Controls & Pvalue \\
\hline Age (median and IQR) & $11 \cdot 5(8 \cdot 8,15 \cdot 2)$ & $11 \cdot 5(8 \cdot 2,15 \cdot 4)$ & $0 \cdot 75^{* *}$ \\
\hline Sex (male) (\%) & $108 / 196(55 \cdot 1)$ & $26 / 55(47 \cdot 3)$ & $0 \cdot 304$ \\
\hline Diarrhoea (\%) & 196/196 (100) & $0 / 55(0)$ & $<0.001$ \\
\hline \multicolumn{4}{|l|}{ Duration (days) } \\
\hline $1-3(\%)$ & $173 / 196(88 \cdot 3)$ & - & - \\
\hline 5 & $12 / 196(6 \cdot 1)$ & - & - \\
\hline$\geq 6$ & $11 / 196(5 \cdot 6)$ & - & - \\
\hline \multicolumn{4}{|l|}{ Episodes $(n) * * *$} \\
\hline $1-4(\%)$ & 24/196 (12.2) & - & - \\
\hline 5 & $86 / 196(43 \cdot 9)$ & - & - \\
\hline$\geq 6$ & $86 / 196(43 \cdot 9)$ & - & - \\
\hline Vomiting (\%) & 182/196 (92.9) & $0 / 55(0)$ & $<0 \cdot 001$ \\
\hline \multicolumn{4}{|l|}{ Duration (days) } \\
\hline $1(\%)$ & $23(12 \cdot 6)$ & - & - \\
\hline 2 & $59(32 \cdot 4)$ & - & - \\
\hline$\geq 3$ & $100(55 \cdot 0)$ & - & - \\
\hline \multicolumn{4}{|l|}{ Frequency $(n)$} \\
\hline$<5(\%)$ & $123(67 \cdot 6)$ & - & - \\
\hline$\geq 5$ & $59(32 \cdot 4)$ & - & - \\
\hline \multicolumn{4}{|l|}{ HIV } \\
\hline Exposed (\%) & 25/196 (12·8) & $6 / 54(11 \cdot 1)$ & $0 \cdot 75$ \\
\hline Infected (\%) & $2 / 58(3 \cdot 5)$ & $0 / 11(0)$ & 0.53 \\
\hline \multicolumn{4}{|c|}{ Completed rotavirus vaccination (\%) } \\
\hline $\begin{array}{l}\text { Vaccinated } \\
\text { (2 doses })\end{array}$ & 194/196 (99.0) & $55 / 55(100)$ & $0 \cdot 45$ \\
\hline $\begin{array}{l}\text { Unvaccinated } \\
\text { (0 dose) }\end{array}$ & $2 / 196(1 \cdot 0)$ & $0 / 55(0)$ & $0 \cdot 45$ \\
\hline \multicolumn{4}{|l|}{ Admitted (\%) } \\
\hline Yes & $111 / 196(56 \cdot 6)$ & - & - \\
\hline Vesikari score (IQR) & $14(12,16)$ & - & - \\
\hline \multicolumn{4}{|l|}{ Temperature (rectal, ${ }^{\circ} \mathrm{C}$ ) } \\
\hline $37 \cdot 1-38 \cdot 4(\%)$ & $92 / 193(47 \cdot 7)$ & - & - \\
\hline $38 \cdot 5-38 \cdot 9$ & 48/193 (24.9) & - & - \\
\hline$\geq 39 \cdot 0$ & $53 / 193(27 \cdot 5)$ & - & - \\
\hline \multicolumn{4}{|l|}{ Thirst (\%) } \\
\hline No thirst & $32 / 196(16 \cdot 3)$ & - & - \\
\hline Thirsty & $141 / 196(71 \cdot 9)$ & - & - \\
\hline Drinks poorly & 23/196 (11·7) & - & - \\
\hline \multicolumn{4}{|l|}{ Skin pinch (\%) } \\
\hline Normal & $56 / 196(28 \cdot 6)$ & - & - \\
\hline Goes back slowly & $104 / 196(53 \cdot 1)$ & - & - \\
\hline Goes back very slowly & $36 / 196(18 \cdot 4)$ & - & - \\
\hline \multicolumn{4}{|l|}{ General appearance (\%) } \\
\hline Well, alert & $94 / 196(48 \cdot 0)$ & - & - \\
\hline Restless & $83 / 196(42 \cdot 4)$ & - & - \\
\hline Unconscious & 19/196 (9·7) & - & - \\
\hline \multicolumn{4}{|l|}{ Dehydration (\%) } \\
\hline None & 26/196 (13·3) & - & - \\
\hline Some $(5 \%)$ & $124 / 196(63 \cdot 3)$ & - & - \\
\hline Severe (10\%) & $46 / 196(23 \cdot 5)$ & - & - \\
\hline
\end{tabular}


IV fluids (\%)

Yes

Oral fluids (\%)

Yes

Outcome (\%)

$$
\text { Home }
$$

Anthropometry, mean (SD)

Adjusted WHZ

Adjusted WAZ

Adjusted HAZ

MUAC

SAM

Previous diarrhoeal admission (\%)

Previous diarrhoeal presentation (\%)

Premature (\%)

Birth weight, mean (SD)

Ever Breastfed (\%)

Diet includes food other than breast milk (\%)

IgA titres at presentation (GMC),

median (range)
$58 / 196(29 \cdot 6)$

185/196 (94.4)

194/196 (99.0)

2/196 (1.0)

$-0.59(1 \cdot 61)$

$-0.46(1.6)$

$-0.04(2.46)$

$13 \cdot 48(1 \cdot 28)$

23/194 (11.9)

$15 / 196(7 \cdot 7)$

$91 / 196(46 \cdot 4)$

$7 / 196(3 \cdot 6)$

$2.96(0.63)$

$195 / 196(99 \cdot 5)$

190/196 (97.0)

$4(0.831)$

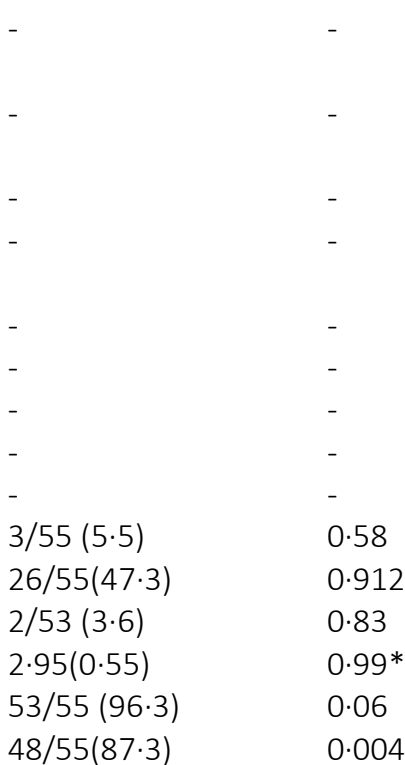

$48 / 55(87 \cdot 3) \quad 0.004$

${ }^{\dagger}$ Chi-squared $p$ values for differences in proportions between case children and control children unless otherwise specified. *2-sided independent ttest **rank sum test ***maximum frequency per day. Abbreviations: interquartlie range (IQR), number $(\mathrm{n})$, degrees Celsius $\left({ }^{\circ} \mathrm{C}\right)$, intravenous (IV), standard deviation (SD), weight-forheight Z score (WHZ), weight-for-age Z score (WAZ), height-for-age Z score (HAZ), mid-upper-arm circumference (MUAC), severe acute malnutrition (SAM), geometric mean concentration (GMC).

\begin{tabular}{|c|c|c|c|c|c|c|}
\hline & \multicolumn{3}{|l|}{ Infection } & \multicolumn{3}{|c|}{ Clinical rotavirus disease } \\
\hline & Case households & Control households & & Case households & $\begin{array}{l}\text { Control } \\
\text { households }\end{array}$ & P-value* \\
\hline Overall & $434 / 665(65 \cdot 3 \%)$ & $40 / 144(27 \cdot 8 \%)$ & $<0.001^{\dagger}$ & $37 / 698(5 \cdot 3)$ & $0 / 153(0 \cdot 0)$ & $0.004^{\dagger}$ \\
\hline \multicolumn{7}{|c|}{ Age stratified (years) } \\
\hline $0-4$ & $57 / 88(64 \cdot 8)$ & $2 / 10(20 \cdot 0)$ & $0.006^{\dagger}$ & $12 / 91(13 \cdot 2)$ & $0 / 11(0 \cdot 0)$ & $0 \cdot 200^{+}$ \\
\hline $5-14$ & $127 / 193(65 \cdot 8)$ & $14 / 48(29 \cdot 2)$ & $<0.001^{+}$ & $4 / 197(2 \cdot 0)$ & $0 / 53(0.0)$ & $0.296^{+}$ \\
\hline $15-45$ & $240 / 367(65 \cdot 4)$ & $5 / 20(27 \cdot 4)$ & $<0.001^{+}$ & $20 / 390(5 \cdot 1)$ & $0 / 87(0.0)$ & $0.031^{+}$ \\
\hline $45+$ & $9 / 16(56 \cdot 3)$ & $1 / 2(50 \cdot 0)$ & $0 \cdot 867^{\dagger}$ & $1 / 18(5 \cdot 6)$ & $0 / 2(0 \cdot 0)$ & $0.732^{\dagger}$ \\
\hline$X^{2} p^{*}$ & 0.894 & 0.838 & & 0.001 & NA & \\
\hline
\end{tabular}

Table 2. Secondary attack rates for rotavirus infection and clinical disease.

*Chi-squared $\mathrm{p}$ value for difference in proportion across age categories

${ }^{\dagger}$ Chi-squared $p$ value comparing difference in proportion between cases and controls

Table 3. Risk factors for transmission of rotavirus infection.

\begin{tabular}{llll}
\hline Variable & OR* & P value & $95 \% \mathrm{Cl}$ \\
\hline Infectiousness risk factors & & & \\
\hline Vesikari score in index child & 1.17 & 0.003 & $1.06,1 \cdot 30$ \\
MUAC* in index child & 1.32 & 0.015 & $1.06,1.66$ \\
\hline Distal susceptibility factors & & &
\end{tabular}

Number of adults with salary in household 
medRxiv preprint doi: https://doi.org/10.1101/2020.04.05.20036574; this version posted April 8, 2020. The copyright holder for this preprint (which was not certified by peer review) is the author/funder, who has granted medRxiv a license to display the preprint in perpetuity.

All rights reserved. No reuse allowed without permission.

None

$\geq 1$

Problems getting food in the past month (\%)

No

Sometimes/often

Proximal susceptibility factors

Relationship with child

Mother

Other adult relative

Child contact

REF

$0 \cdot 29$

0.44

0.000

0.002

0.08

$0.31,1.06$

$0 \cdot 58$

\section{(a)}

* OR indicates odds ratio, MUAC indicates Mid Upper Arm Circumference. Odds ratio for Vesikari score and

MUAC are per variable unit

\section{7}

Table 4. Risk factors for rotavirus disease transmission.

\begin{tabular}{|c|c|c|c|}
\hline & OR & $P$ value & $95 \% \mathrm{Cl}$ \\
\hline \multicolumn{4}{|l|}{ Infectiousness risk factors } \\
\hline Vesikari score in index child & $1 \cdot 28$ & 0.005 & $1.08,1.52$ \\
\hline \multicolumn{4}{|c|}{ Rotavirus genotype, index child } \\
\hline $\mathrm{G} 1 \mathrm{P}[8]$ & REF & & \\
\hline G2P[4] & $0 \cdot 36$ & 0.059 & $0.12,1.03$ \\
\hline $\mathrm{G} 2 \mathrm{P}[6]$ & 0.43 & $0 \cdot 219$ & $0.11,1.64$ \\
\hline $\mathrm{G} 12 \mathrm{P}[6]$ & $0 \cdot 82$ & 0.759 & $0.23,2 \cdot 95$ \\
\hline Other & $1 \cdot 10$ & $0 \cdot 842$ & $0.44,2 \cdot 71$ \\
\hline \multicolumn{4}{|l|}{ Distal susceptibility factors } \\
\hline \multicolumn{4}{|l|}{ Toilet type } \\
\hline None & REF & & \\
\hline Simple pit/VIP* & 0.56 & $0 \cdot 484$ & $0 \cdot 11,2 \cdot 83$ \\
\hline Water toilet & 0.42 & 0.520 & $0.03,5.96$ \\
\hline \multicolumn{4}{|l|}{ Proximal susceptibility factors } \\
\hline \multicolumn{4}{|l|}{ Household member age } \\
\hline$<5$ years & REF & & \\
\hline $5-15$ years & $0 \cdot 13$ & 0.001 & $0.04,0.46$ \\
\hline $15-45$ years & 0.38 & 0.031 & $0.17,0.92$ \\
\hline $45+$ years & $0 \cdot 35$ & $0 \cdot 351$ & $0.04,3 \cdot 22$ \\
\hline
\end{tabular}


medRxiv preprint doi: https://doi.org/10.1101/2020.04.05.20036574; this version posted April 8, 2020. The copyright holder for this preprint (which was not certified by peer review) is the author/funder, who has granted medRxiv a license to display the preprint in perpetuity.

All rights reserved. No reuse allowed without permission.

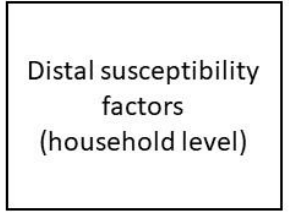

Proximal susceptibility factors (individual contacts)
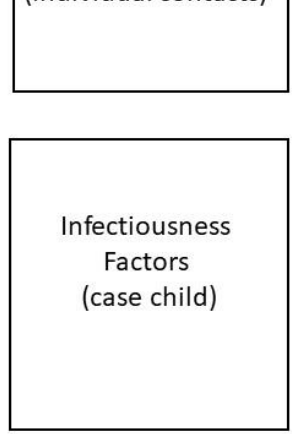
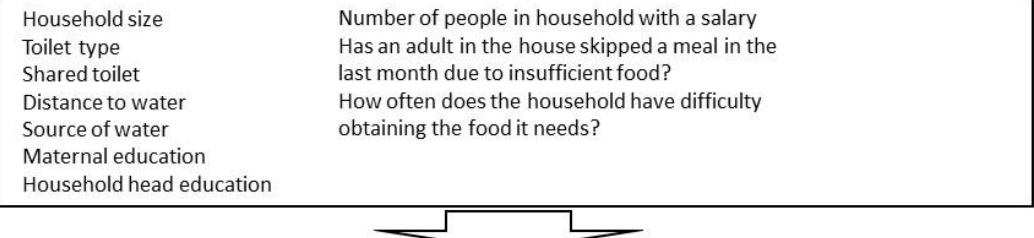

Relationship to child Human Immunodeficiency Virus Under $\mathbf{5}$ household contacts only

$\begin{array}{lll}\text { Share room with child } & \text { (HIV) status } & \text { Rotavirus vaccine status }\end{array}$

Share bed with child

Share toilet with child

Age of household contact

Primary care giver for child

Prematurity

Responsibility for changing nappy Birth weight

Weight-for-height Z score (WHZ)

Weight-for-age Z score (WAZ)

Height-for-age Z score (HAZ)

Time spent in house

\begin{tabular}{|lll|}
\hline Age & WAZ & Dehydration \\
Sex & HAZ & Thirst \\
HIV exposure & MUAC & Temperature \\
HIV infection & Vesikari score & Skin pinch \\
Prematurity & Diarrhoea duration (days) & General appearance \\
Birth weight & Diarrhoea frequency (per day) & Outcome \\
Breast feeding & Vomiting & Admission \\
Rotavirus vaccine status & Vomiting frequency & Viral load \\
WHZ & Vomiting duration & Anti-rotavirus IgA titres \\
& & Genotype of rotavirus \\
\hline
\end{tabular}

472 Figure 1.

473

\section{Unvaccinated children}

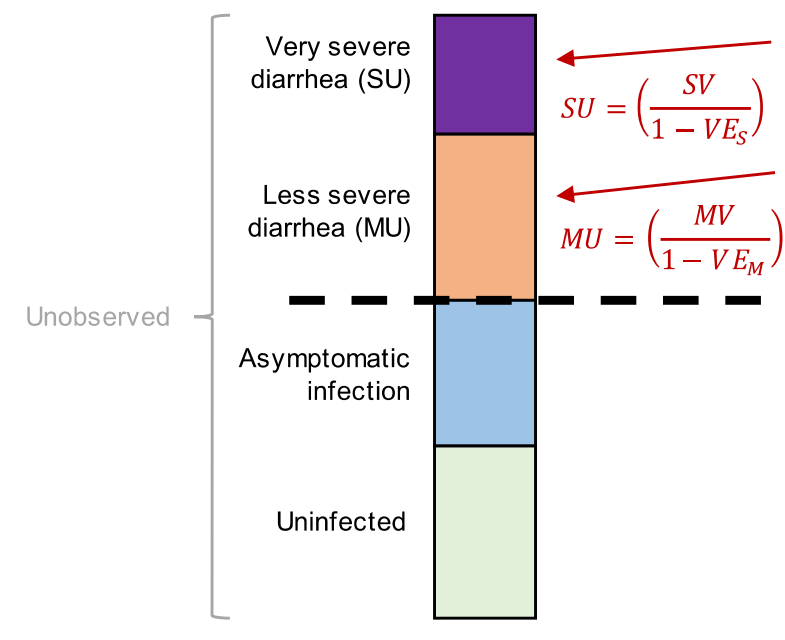

Vaccinated children

\section{$474 \quad$ Figure 2.}


medRxiv preprint doi: https://doi.org/10.1101/2020.04.05.20036574; this version posted April 8, 2020. The copyright holder for this preprint (which was not certified by peer review) is the author/funder, who has granted medRxiv a license to display the preprint in perpetuity.

All rights reserved. No reuse allowed without permission.

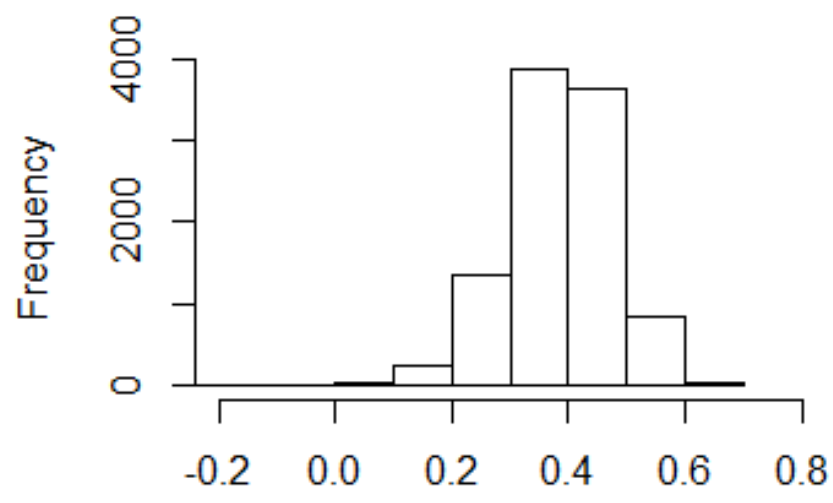

VE Transmission

475

476 Figure 3.

477

478 